\title{
5. THE IAŞI SCHOOL OF PAINTING - BETWEEN MYTH AND REALITY
}

Mirela Ștefănescu ${ }^{201}$

\begin{abstract}
This paper analyzes a phrase which is specific of cultural space from Iași called "The Iași School of Painting", a term which, as art critics say, is distinguished by several features including the harmony of the composition, the chromaticism and refinement of artistic expression. So, we start in this study with the founders of the first institution of artistic education in Iasi, which strongly influenced the local creative style of plastic expression, then, we talk about the period in which was materialized fully the traditional way of the Iasi school of painting. After December 1989 the visual art from Iasi has gone through many changes, being outlined a new approach to the artistic phenomenon in the context of technological development and the globalization, the moment in which the visual artists tried new plastics formulas. Today the expression the Iasi School of Painting is only a metaphor which illustrates the connection with the glorious past of the great masters.
\end{abstract}

Key words: The Iași School, traditional style, harmony of composition, chromaticism

\section{Introduction}

In the art critics' opinion, among the attributes of the Iaşi School of Painting, we distinguish the composition artistry and harmony, the chromatic material mastery, the refinement and sensibility and, like any current, school, wave, it creates more ambiguities that do not appear at a certain moment and do not suddenly disappear. The Academicism, as an artistic principle, was approached as a "bourgeois realism", which was based on a set of rules accepted by both artists and art audience.

\section{Precursors of The Iaşi School of Painting}

The teachers of the Belle Arte School of Iaşi, educated in Munich, applied the same principles as the Bavarian teachers, so that the successes from the field of historical compositions, portraits, still lives, included both the greatness and the twilight of the current. We can mention that, since 1860, with the founding of the Belle Arte School of Iaşi and of the first national Pinacoteque, reference names like Gheorghe Panaiteanu - Bardasare, Gheorghe Năstăseanu, Gheorghe Şiller, C.D. Stahi, Emanoil Bardasare, Octav Băncilă, Theodor Pallady, and Otto Brise strongly influenced the cultural atmosphere and the artistic taste of Iaşi, bringing their contribution to the defining of the Romanian art history specificity $^{202}$.

\footnotetext{
201 PhD., "George Enescu” National University of Arts from Iaşi, Romania, email: mirela_stefanescu@yahoo.com

202 Pentru mai multe detalii asupra stilului acestor maeștri, vezi și Ioana-Iulia Olaru, în aticolul 155 Years of Artistic Education in Iași. An Art under the Sign of Academic Tradition, in vol. Debates on Globalization. Aproaching National Identity through Intercultural Dialogue, Iulian Boldea (coord.), Ed. Arhipelag XXI Press, 2015, p.750-756
} 

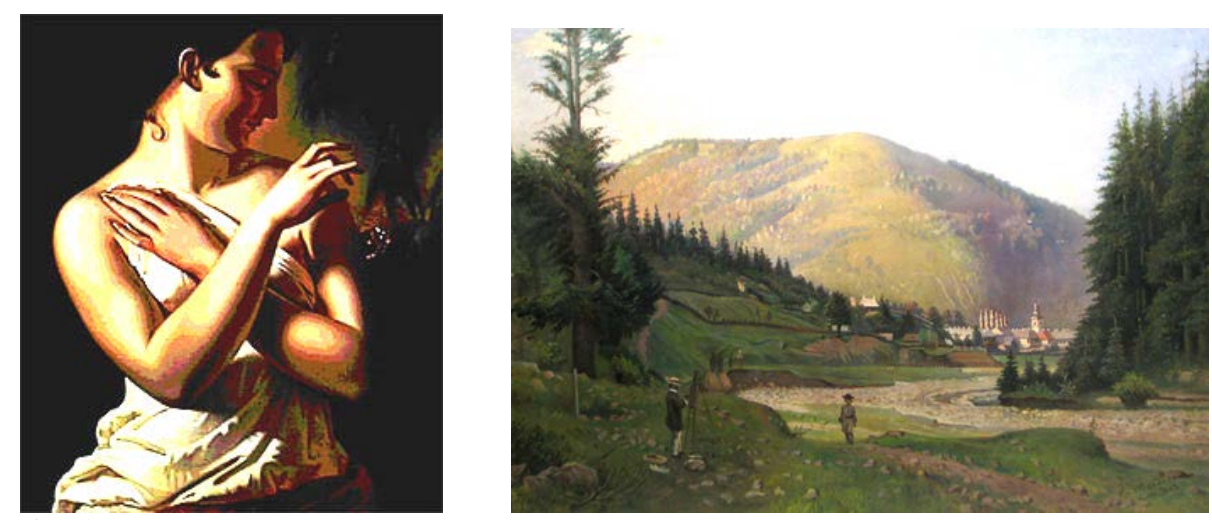

Fig. 1. Gheorghe Panaiteanu Bardasare - Fata cu fluturele 203

Fig. 2. Emanoil Panaiteanu-Bardasare - Peisaj Mănăstirea Agapia ${ }^{204}$
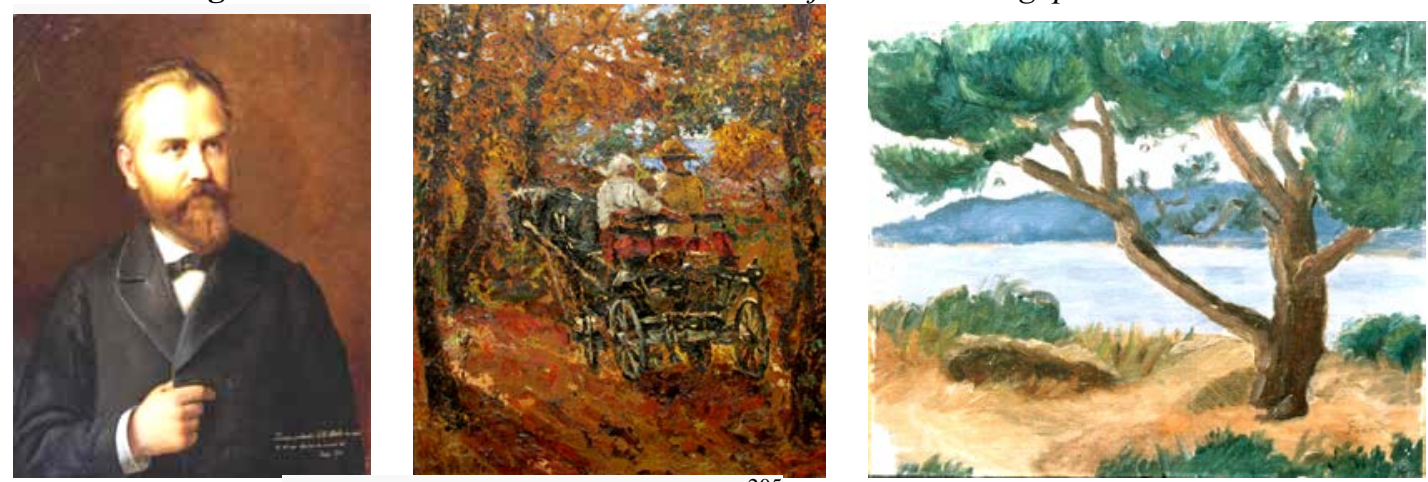

Fig. 3. Constantin D. Stahi - Autoportret ${ }^{205}$

Fig. 4. Octav Băncilă - În pădure 206

Fig. 5. Theodor Pallady-Peisaj din Franța207

In the Western artistic field, the artistic movements followed quickly one another, fact which was not neglected in Iassi, but the noisy searches of the avant-garde remained without echo, the "calmer" styles - like those of Impressionism or of the "Art Nouveau" movement being preferred. During this period artists such as Ştefan Dimitrescu, who aimed at changing the shape and background of the life and the art school of Iaşi, make themselves conspicuous. "The academic and conservative spirit, opposed to changes and instaurations, as cultivated and preserved by the long-standing director Gheorghe Popovici and his teachers assembly, persisted eagerly, even when facing Ştefan Dimitrescu's new educational vision." ${ }^{208}$ Nicolae Tonitza, Francisc Șirato, Oscar Han etc. drew, through composition structure, chromatic refinement and sentimentalsymbolic visions, the direction of the Iaşi School of Painting.

\section{The Iaşi School of Painting Followers}

The following generations of plastic artists, such as Nicolae Popa, Nutzi Acontz, Mihai Cămăruț, Victor Mihăilescu Craiu, Călin Alupi, Petre Hârtopeanu, Costache Agafiței, Corneliu Baba ${ }^{209}$, Eugen Ștefan Boușcă ${ }^{210}$, Dan

\footnotetext{
203 https://www.google.ro/search?q=Gheorghe+Panaiteanu-Bardasare;

${ }^{204}$ https://ro.wikipedia.org/wiki/Emanoil_Panaiteanu-Bardasare;

205 https://ro.wikipedia.org/wiki/Constantin_Stahi

${ }^{206} \mathrm{https}: / /$ www.google.ro/search?q=octav+bancilă

${ }^{207}$ https://www.google.ro/search?q=theodor+pallady

${ }^{208}$ Valentin Ciucă, Note despre Școala ieșenă de pictură, în Revista Dacia Literară, nr. 46, (3/ 2002), Iași

${ }^{209}$ Recunoscut la maturitate ca un clasic în viață, fidel unui realism transfigurat

210 „Sunt eminamente un produs al acestei școli ieșene... am căutat să exprim culorile moldovenești, culorile cerului de apus, oranj și liliachiu” (Ștefan Boușcă)
} 
Hatmanu and Adrian Podoleanu, the sculptors Ion Irimescu, Iftimie Bârleanu, Vasile Condurache, Vladimir Florea, and Dumitru Căileanu, fully embodied the common traditionalist and, at the same time, individual style ${ }^{211}$.
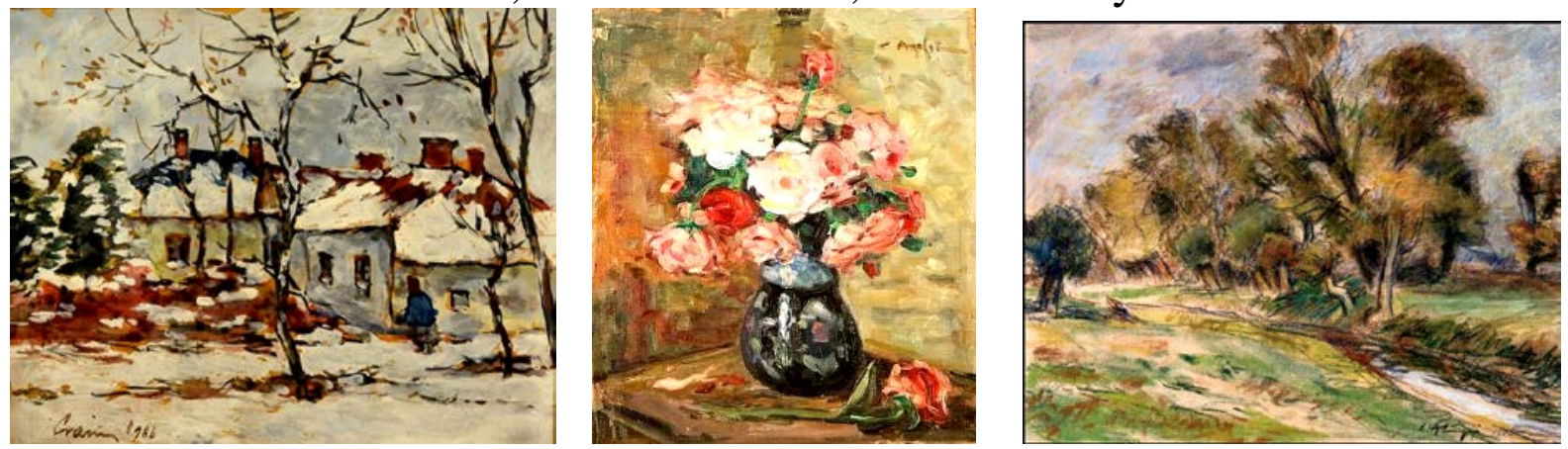

Fig. 6. Victor Mihăilescu Craiu, Iarna în mahalaua Iașului 212

Fig. 7. Călin Alupi, Lunca ${ }^{213}$

Fig. 8. Costache Agafiței, Vas cu flori ${ }^{214}$

Despite some changes in both the education system and the artists' behaviour, in Iaşi, "an idleness in poaching the avant-garde aesthetics, maybe too rebellious in relation to the great lesson of nature and the visible" ${ }^{215}$ was obvious.
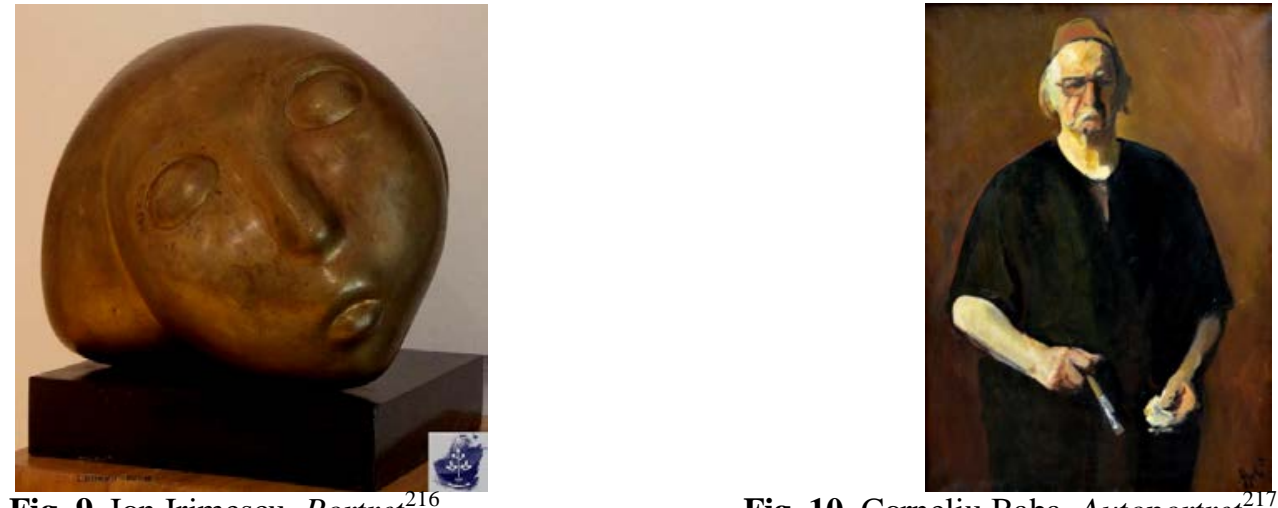

Fig. 9. Ion Irimescu, Portret

Fig. 10. Corneliu Baba, Autoportret ${ }^{2}$

In the communist era, the artists from Iaşi managed to maintain a balance between the traditional formulas and "the party demand", many of them trying to "save themselves" by subtle dissimulation ways, namely by consciously maintaining the conservative plastic tone. Forced by the political situation, the plastic artists from Iaşi "hesitated between the vocabulary of tradition and that of modernity, some bravely detaching themselves from the conservative, slightly anachronistic, obviously dominant $<<$ grip $>>$., ${ }^{218}$ We can say that artists who did not put to a test certain professional values, through "inappetence to innovation

\footnotetext{
${ }^{211}$ Despre unii dintre acești artiști, vezi și Ioana-Iulia Olaru, în articolul Aniversary Time: 155 Years of ArtRelated Education in Iași. The Crisis Years up to the Moment 1989. Artistic Liberalization, in vol. Discourse as a Form of Multiculturalism in Literature and Communication, Iulian Boldea (coord.), Ed. Arhipelag XXI Press, 2015, p.103-109

212 http://artindex.ro/2012/05/16/mihailescu-craiu-victor/

${ }^{213}$ https://www.google.ro/search?q=calin+alupi

${ }^{214} \mathrm{https} / / /$ www.google.ro/search?q=costache+agafitei+pictor

${ }^{215}$ Valentin Ciucă, Un secol de Arte frumoase la Iași, Ed. ArtXXI, Iași, 2004, p.10

${ }^{216}$ http://ghidulmuzeelor.cimec.ro/id.asp?k=561\&imgord=10\&-Muzeul-de-Arta-Ion-Irimescu-FALTICENISuceava

${ }^{217}$ https://www.google.ro/search?q=corneliu+baba

${ }^{218}$ Petru Bejan, Lumea artei. Tîrcoale critico-hermeneutice, Ed. Fundația Academice Axis, Iași, 2012, p.124
} 
or inappropriate themes and techniques... I would see here the signs of a clear deficit." 219

In the bohemian spirit of the sweet townlet of Iassi, the artists were indulging themselves in a "bourgeois cosiness"220, untouched by cosmopolitanism, the Iaşi bohemia producing artists considered "waggish and chatty, funny and indifferent to too noisy insurrections."221

However, the new generations of artists (the sixth decade of the twentieth century) were adamant, following an individual artistic program, practicing a specific figurative art, in the spirit of a modernist vision. Strong characters such as Ion Neagoe, Francisk Bartok, Ioan Gânju, Nicolae Mátyus, Corneliu Ionescu, Agneta Covrig, Liviu Suhar, Dan Covătaru, and Dimitrie Gavrilean "redesigned" the artistic landscape of Iaşi. It is a stage represented by a lyrical dominance, a concern for the landscape, for chromatism, through which the school of Iaşi always excelled by the accuracy of the technique execution.
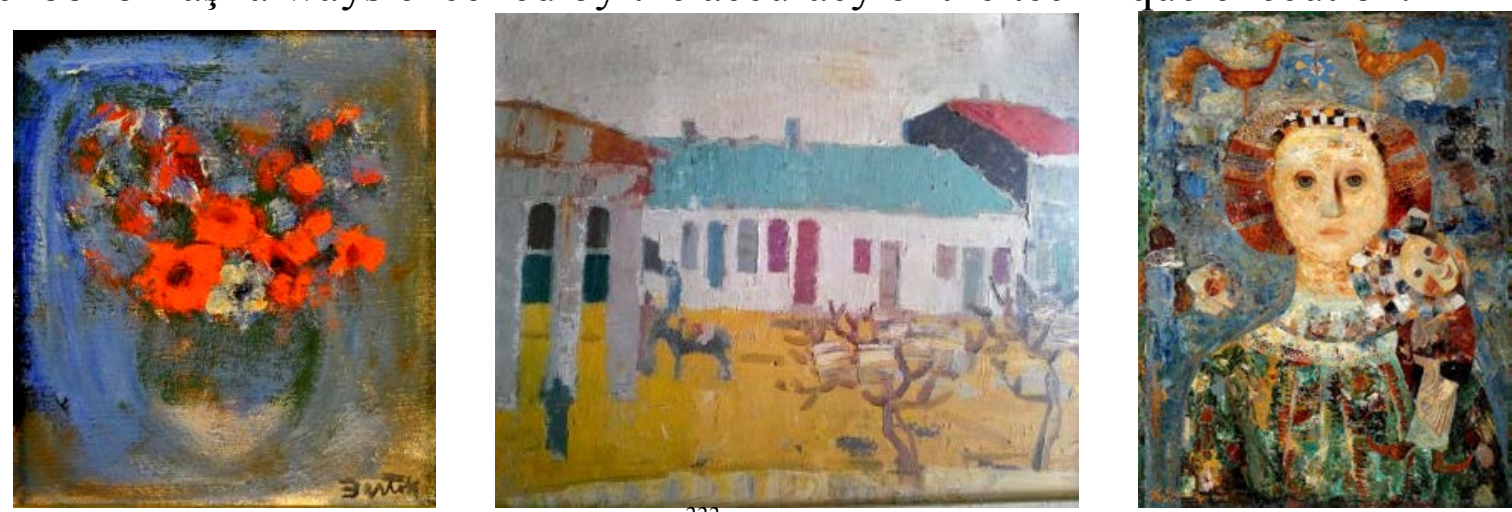

Fig. 11. Francisk Bartok Vas cu flori roşii ${ }^{222}$

Fig. 12. Nicolae Matyus, Peisaj din Tulcea ${ }^{223}$

Fig. 13. Dimitrie Gavrilean, Păpușarul ${ }^{224}$

\section{The Iaşi School of Painting and new stylistic searches following December, 1989}

Along with the new postdecembrist openings, after the year 1989, various aesthetic tendencies have evolved, causing a seemingly confusing state in the artistic landscape of Iaşi. The sudden changes and the many chaotic images have not upset the artists of Iaşi, who reacted with their usual calm, refusing the challenges foreign to the Moldavian spirit. The oscillating options between tradition and innovation, figurative and nonfigurative, realism or abstractionism have been the artistic research directions in all Visual Art genres.

In this creative context, the next generation of artists has oscillated between the areas of the imaginary, between reality and fantastic. Representative artists for this period are Valeriu Goncariuc, Jenö Bartos, Dragoș Pătrașcu, Mihai Tarași, Constantin Tofan, Traian Mocanu, Ichim Alexandru, Pavel Marcel,

\footnotetext{
${ }^{219}$ Ibidem, p. 10

${ }^{220}$ După cum spunea Jenö Bartos în interviul realizat de Mirela Ștefănescu, 2017

${ }^{221}$ Valentin Ciucă, op. cit., p.10

${ }^{222}$ https://www.google.ro/search?q=francisc+bartok+pictor

${ }^{223} \mathrm{https} / / / \mathrm{www}$.google.ro/search?q=Nicolae+Matyus

${ }^{224}$ https://www.google.ro/search?q=dimitrie+gavrilean+pictor
} 
Gabriela Agafiței, Bogdan Bârleanu and others, detached authors who have sought new visual solutions, new plastic expressions.
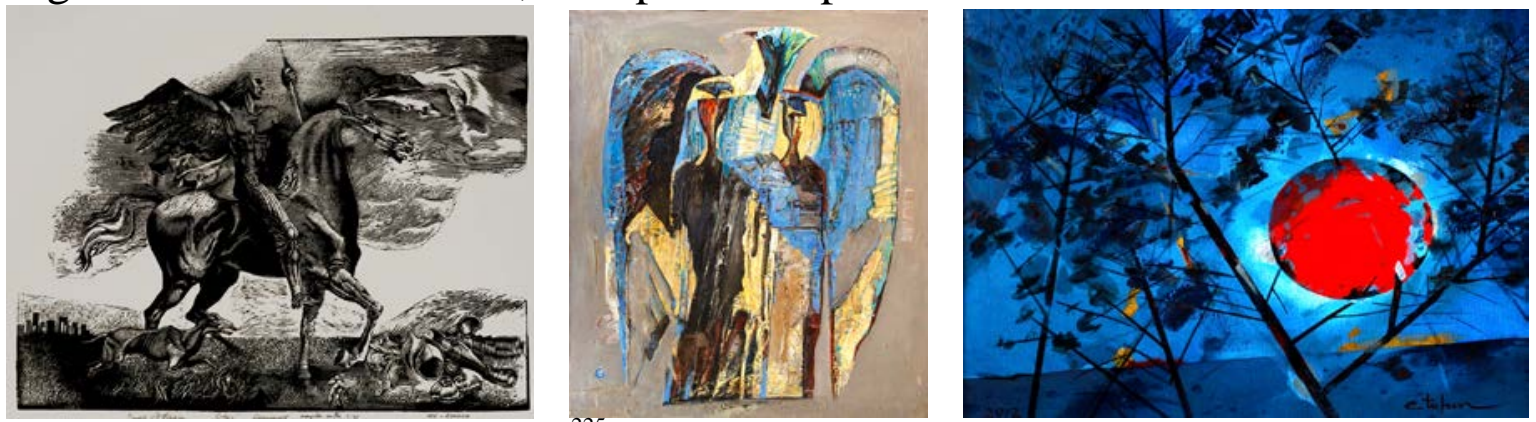

Fig.14. Dragoș Pătrașcu, Victorie $e^{225}$

Fig. 15. Jenö Bartos, Izgonirea din Rai ${ }^{226}$

Fig. 16. Constantin Tofan, La luna ${ }^{227}$

The search for a path of their own also characterizes the new generation of plasticians, who continue the traditions regarding the identity and the cultural specificity of Iaşi, among which the painters Felix Aftene, Zamfira Bîrzu, Ion Pricop, Valentina Druțu and others, the sculptors Gabriela Drînceanu, Mircea Ștefănescu, Lucian Smău etc., as well as representatives of other visual genres such as Ramona Biciușcă, Radu Carnariu or Dan Acostioaei and others. "The creative energies have been channeled more toward the search for new plastic expression media than toward fathoming the styles claimed by various artistic groups" $^{228}$.

In this context, it should be noted that most of the visual artists mentioned in this article were or are professors at the "George Enescu" National University of Arts, Iaşi, carrying out a prestigious didactic activity - according to the visual arts standards of the Romanian Agency for Quality Assurance in Higher Education - finding the best solutions to promote young artists and looking for "new programs in line with the labor market dynamics"229, bringing their contribution to the visibility of the artistic higher education institutions of Iaşi city.
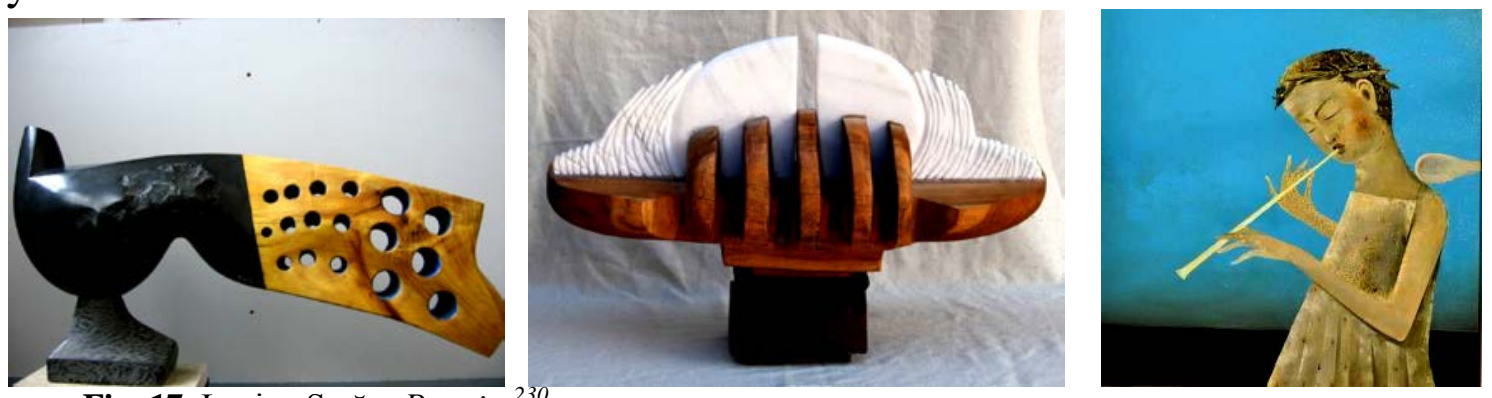

Fig. 17. Lucian Smău, Paunița

Fig. 18. Mircea Ștefănescu, Luceafar 231

Fig. 19. Felkix Aftene, Vestitor 232

\footnotetext{
${ }^{225} \mathrm{https}: / /$ www.google.ro/search?q=dragoș+pătrașcu

${ }^{226} \mathrm{https} / / / \mathrm{www}$. google.ro/search?q=bartos+jeno

${ }^{227}$ https://www.google.ro/search?q=constantin+tofan

${ }^{228}$ Mircea Ștefănescu, Seria Puppyes creată de Jeff Koons, în Revista Lucrări Științifice a Facultății de Horticultură din cadrul USAMV Iași, vol. 57 , nr.1, Ed. „Ion Ionescu de la Brad”, Iași, 2014

${ }^{229}$ Eugenia Maria Pașca, Variables and constants in the curriculum for the music specialisations of the romanian university education, Review of Artistic Education no. 11-12, 2016

${ }^{230} \mathrm{http}: / /$ uapriasi.ro/smau-lucian-constantin/

${ }^{231} \mathrm{http}: / /$ uapriasi.ro/mircea-stefanescu/
} 
"In the context of the so-called postmodern artistic current, the connection between the Iassi School of Painting and the current aesthetic orientations seems to have "melted" in the highly diversified palette of new artistic expression forms, both in the traditional specializations area, painting, sculpture, graphics, decorative arts, as well as in the new specializations one, photo, video computerized image processing and New Media." 233

In the contemporary visual art, the trend is that of disengagement from the traditional figurative forms of plastic expression, evolving toward new visual language areas in the context of globalization and exhibition dynamics ${ }^{234}$. The influence of globalization and of the current technological development have persuaded the visual artists to search for general styles that fit best with the approached subjects, adding new dimensions to the creative process, by plastic means suited to a dynamic and ever-evolving world. ${ }^{235}$

\section{Conclusions}

At the end of this analysis, we find that, nowadays, the Iassi School of Painting phrase is but a metaphor that illustrates the connection with the glorious past of the great masters, of a nostalgic epoch, an expression that evokes the love of Iaşi for painting, for culture, a sign of a particular spirituality.

\section{Books:}

\section{Bibliography}

1. Bejan, Petru, (2012), Lumea artei. Tîrcoale critico-hermeneutice, Ed. Fundația Academice Axis, Iași

2. Ciucă, Valentin, (2004), Un secol de Arte frumoase la Iaşi, Ed. ArtXXI, Iași,

3. Sava, Valentin, (2010), Invăţământul artistic naţional ieşean şi vocaţia lui europeană, Ed. Artes, Iaşi,

4. Simionescu, Atena, Elena, (2015), Istoricul UAGE 1860 - 2015 - 155ani de invățământ artistic modern la Iași, Partea I - 1830-1950, Ed. Artes, Iași,

5. Zaharia, Dumitru N., (2000), Iaşul Vernisajelor, vol. II, Ed. Dosoftei, Iaşi

\section{Articles:}

1. Ciucă, Valentin, (1990), Idividualitate și grup, publicat în Cronica nr. 51/52 din 21.12.1990

2. Ciucă Valentin, (2002), Note despre Școala ieșenă de pictură, publicat în Revista Dacia Literară, nr. 46, (3/ 2002), Iași

3. Olaru, Ioana-Iulia, (2015), 155 Years of Artistic Education in Iași. An Art under the Sign of Academic Tradition, in vol. Debates on Globalization.

\footnotetext{
232 https://www.google.ro/search?q=felix+aftene

233 După cum afirma Valentin Sava în interviul realizat de Mirela Ștefănescu, 14 septembrie 2017

234 Ştefãnescu Mircea, Ştefãnescu Mirela, Land Art - The harmony between art, nature, landscape, în Revista Lucrări Științifice a Facultății de Horticultură din cadrul USAMV Iași, vol. 57 , nr.1, Ed. „Ion Ionescu de la Brad”, Iași, 2014

235 Mirela Ștefănescu, Arta vizuală ieșeană între tradiție și inovație, Review of artistic education, nr. 1314/2017, Ed. Artes, Iași, 2017
} 
Aproaching National Identity through Intercultural Dialogue, Iulian Boldea (coord.), Ed. Arhipelag XXI Press, p.750-756

4. Olaru, Ioana-Iulia, (2015), Aniversary Time: 155 Years of Art-Related Education in Iași. The Crisis Years up to the Moment 1989. Artistic Liberalization, in vol. Discourse as a Form of Multiculturalism in Literature and Communication, Iulian Boldea (coord.), Ed. Arhipelag XXI Press, p.103109

5. Pașca, Eugenia, Maria, (2016), Variables and constants in the curriculum for the music specialisations of the romanian university education, Review of Artistic Education no. 11-12, 253-262

6. Ștefănescu, Mirela, (2017), Arta vizuală ieșeană între tradiție și inovație, în Review of artistic education, nr. 13-14/2017, Ed. Artes, Iași, 2017, p. 221 - 226

7. Ştefănescu, Mircea, Ştefănescu, Mirela, (2014), Land Art - The harmony between art, nature, landscape, publicat în Revista Lucrări Ştiințifice a Facultăţii de Horticultură din cadrul USAMV Iași, vol. 57 , nr.1, Ed. „Ion Ionescu de la Brad", Iaşi

8. Ștefănescu, Mircea, (2014), Seria Puppyes creată de Jeff Koons, publicat în Revista Lucrări Știinţifice a Facultăţii de Horticultură din cadrul USAMV Iași, vol. 57 , nr.1, Ed. „Ion Ionescu de la Brad”, Iași

\section{WEB pages:}

1. https://www.google.ro/search?q=felix+aftene, 17.07.2017

2. https://www.google.ro/search?q=costache+agafitei+pictor, 17.07.2017

3. https://www.google.ro/search?q=calin+alupi, 17.07.2017

4. https://www.google.ro/search?q=corneliu+baba, 17.07.2017

5. https://www.google.ro/search?q=octav+bancilă, 17.07.2017

6. https://www.google.ro/search?q=Gheorghe+Panaiteanu-Bardasare, 17.07.2017

7. https://ro.wikipedia.org/wiki/Emanoil_Panaiteanu-Bardasare, 17.07.2017

8. https://www.google.ro/search?q=bartos+jeno, 17.07.2017

9. https://www.google.ro/search?q=francisc+bartok+pictor, 17.07.2017

10. http://artindex.ro/2012/05/16/mihailescu-craiu-victor/, 17.07.2017

11. https://www.google.ro/search?q=dimitrie+gavrilean+pictor, 17.07.2017

12. http://ghidulmuzeelor.cimec.ro/id.asp?k=561\&imgord=10\&-Muzeul-deArta-Ion-Irimescu-Falticeni-Suceava,17.07.2017

13. https://www.google.ro/search?q=Nicolae+Matyus, 17.07.2017

14. https://www.google.ro/search?q=theodor+pallady, 17.07.2017

15. https://www.google.ro/search?q=dragoș+pătrașcu, 17.07.2017

16. http://uapriasi.ro/smau-lucian-constantin/,17.07.2017

17. https://ro.wikipedia.org/wiki/Constantin_Stahi, 17.07.2017

18. http://uapriasi.ro/mircea-stefanescu/,17.07.2017

19. https://www.google.ro/search?q=constantin+tofan, 17.07.2017 